\title{
The Effect of Dutch Disease on Trade Openness and Foreign Direct Investment in Algeria
}

\begin{abstract}
This study aims to explain the poor performance of trade openness and foreign direct investment recorded in Algeria the last few years. The period of the study extends from 2004 to 2013. Using a time series data type, a classic linear regression model has been adopted in order to test hypotheses and explain the relationship between natural resource dependence and the performance of trade openness and foreign direct investment. SPSS software for windows version 19 has been used for statistical analysis which revealed several findings, essentially that there is a negative relationship between natural resource dependence and trade openness and foreign direct investment performances, which means that an increase of resource dependence results in a decrease in both trade openness and foreign direct investment.

Keywords: Dutch Disease, Resource Curse, Rentier State, Trade Openness, Foreign Direct Investment.

\section{Soufiane BOUSSALEM}

Faculty of Economic, Management and Commercial Sciences University of Oum El Bouaghi

\section{Azzedine BENTERKI}

Faculty of Economic, Management and Commercial Sciences

University of Constantine 2 (Algérie)
\end{abstract}

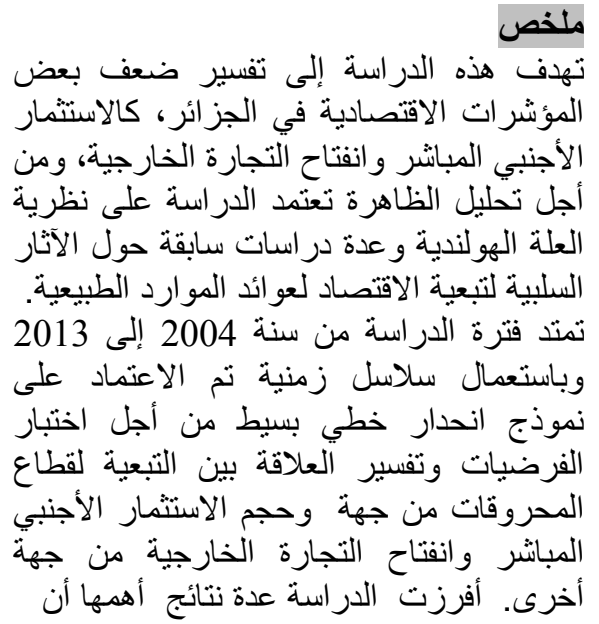

\section{Introduction}

\begin{abstract}
Algerian economy has long been characterized by a hydrocarbons sector domination, which defines the country as a rentier state and therefore highly dependent on oil revenues and the sector's performance. This characteristic of the Algerian economy has always been identified as a huge disadvantage by both economists and Algerian government, this concern is understandable and justified as the prosperity of the country is highly sensitive to oil prices and therefore vulnerable. History and statistics show that high oil prices have positive impact on
\end{abstract}


هناك علاقة سلبية ذات دلالة إحصائية بين

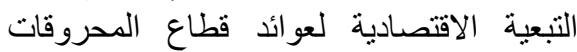

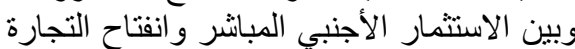

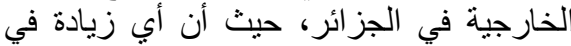

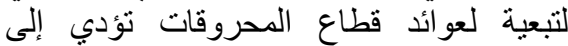
انخفاض انفتاح التجارة الخارجية و والاستثمار الأجنبي المباشر.

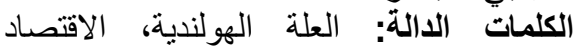
الريعي، النفاح التجارة، الاستة: الأنثار الأجنبي المباثر. economic performance of the country and growth; low prices however have devastating effects on the economy and society, low oil prices have driven the country into a severe crisis back in the 80 s which resulted in a huge public debt and social problems.

Therefore, the government has been trying for many years to increase exports of other sectors, reduce dependence and build a strong manufacturing sector by taking several procedures, including the

encouragement of foreign direct investment and trade openness. Thus, there are no significant results as oil revenues still constitute more than $90 \%$ of Algerian revenues. The question we are addressing in this paper and which was addressed by many economists, is why Algeria keep failing to deliver any significant results when it comes to boosting economic performance aside of the hydrocarbons and build strong manufacturing sector, despite all the measures taken by the government and despite all the revenues made thanks to the oil prices boom? Furthermore, the focus of the study is foreign direct investment and trade openness in Algeria. There are many study cases in literature which are similar to the Algerian case, most of the studies refer to the resource curse or the Dutch Disease syndrome in order to explain the poor economic performance, and this study also is based on the Dutch Disease and the resource curse theories.

\section{Literature review:}

\subsection{Rentier states economy:}

Rent can be defined as nature's reward for ownership of resources (1). Rent can be found within every country but at variant degrees, the country is considered as a rentier state if percentage of natural resource revenues is too high compared to other sources of the government's revenues. The economy of a country is considered as resourcebased if natural resource revenues make $10 \%$ of GDP and $40 \%$ of exports.(2)

Today, more and more economists consider natural resources abundance as a curse; this conclusion is justified by numerous researches and studies which show that relying too much on natural resource revenues will slow down economic development, growth and has negative effects on the industry. Furthermore, as a matter of fact most rentier states are within the developing world.(3) However, these revenues have a lot of positive effects for the country, it pay for social services, and helps create a middle class, increase per capita GDP and raise other measures of development .(4)

\subsection{What is Dutch Disease?}

Originally the Dutch Disease term was used to designate an economic situation lived in Netherland in the late 50 s and early 60 s, after the discovery of a large source of natural gas in the North Sea. Following this discovery a large capital inflow resulted from increasing exports caused the appreciation of the Dutch currency which reduced significantly both profitability and competitiveness of the manufacturing and service 
sectors in the international market (5). Generally, economists use the term Dutch Disease to describe a lack of profitability, competitiveness and overall performance of a country's exports and industry caused by a discovery of natural resource or a booming sector within the economy. (6)

Corden and Neary (7) define Dutch Disease as the coexistence of booming and declining sub-sectors within the traded goods sector of a country, in many cases the booming sub-sector is of an extractive kind while the declining one is the manufacturing sector, which causes de-industrialization of the country.

\subsection{The effects of Dutch Disease:}

In order to explain the Dutch Disease phenomenon, Corden and Neary highlighted two major effects of the booming sector, the spending and the resource movement effects which cause both direct and indirect de-industrialization (8) . In order to explain the Dutch Disease effects a number of hypotheses have been set, most importantly that monetary considerations are ignored, all goods are used for final consumption only, full employment reached and trade is always balanced. (9)

The core model of the Dutch Disease theory's structure consists of a small open economy composed of three sectors, two of them produce tradable goods which prices are fixed on an international level, and the third is a non-tradable goods sector which prices are flexible to meet demand fluctuations. The booming sector is assumed to be energy, the second tradable goods sector is manufacturing and the non-tradable goods sector is services. (10)

The spending effect occurs from the extra spending on non tradable goods, resulted from higher income caused by the boom (11). This spending may be direct from factor owners or indirect by the government after tax collection. Eventually, this income leads to higher demand for non tradable goods, therefore, the prices of these goods shall rise and move mobile production factors from the manufacturing sector toward the non tradable goods sector in order to increase output and meet the new demand level, this effect is considered as an indirect de-industrialization . (12)

The resource movement effect is a direct result of the boom. The boom increases demand for production factors in order to achieve higher output. Therefore, the booming sector attract and absorb mobile production factors such as labor and capital from the other two sectors of the economy, which causes an output fall in both service and manufacturing sectors and this is considered as a direct de-industrialization (13) . In other words, the spending effect has positive consequences on the service sector and negative consequences on manufacturing, this effect cause indirect de-industrialization. The resource movement effect has negative consequences on both service and manufacturing, this effect causes direct de-industrialization. It is worth noting that eventually the non-tradable goods sector's output maybe higher or lower than the initial level before the boom, depending on the intensity of the spending and resource movement effects. (14)

Beside Corden and neary's work, many empirical studies (15) have provided evidence that natural resource reliance has a negative impact on economic growth of the country in the long term. Other recent studies (16) show that there is no direct 
impact of natural resources on poor industrial performance. Thus, these studies provide empirical evidence that there is indirect impact, if natural resource abundance increases this will encourages corruption which then will have a significant negative impact on economic growth. The main symptoms of Dutch Disease found in literature are the lack of export diversity, overvalued currency, poor industrial performance, high level of corruption, low foreign investment and low human capital investment. Furthermore, there is no consensus in literature about the mechanism of the Dutch Disease and the way natural resource dependence affects economic growth on the long term. Thorvaldur (17) pointed four main approaches explaining the effect of natural resource abundance on economic growth basing on literature and previous studies. First, overevaluated currency is caused by the natural resources price fluctuations on both fixed and floating exchange rates, which leads to low export performance, low trade openness and low foreign investment. Considering that these variables are good for economic growth means that natural resource abundance has a negative effect on economic growth of the country. The second way to explain the resource curse is that weak markets and legal structures enhance rent seeking behavior, this behavior deprives resource allocation to other valuable sectors and social activities. Furthermore, rent seeking behavior leads to power concentration in the hands of few people who then use rent money for personal interests and to preserve their power, in some severe cases this behavior may end up with a civil war. Also, corruption which is another result of the rent seeking behavior is a significant variable when explaining the resource curse. Studies have found that there is a significant correlation between natural resource dependence and corruption index, in the other hand there is a significant correlation between corruption and economic growth and therefore natural resource abundance indirectly affects economic growth.

The third approach used to explain the Dutch Disease mechanism is based on human capital and education. According to this approach education and human capital investment is negatively correlated to natural resource abundance, which can be extremely harmful to the economy considering that education and human capital accumulation are essential for economic growth. Finally, natural resource abundance lowers domestic investment and saving and may weaken financial institutions of the country, which also can severely harm economic growth.

\section{Empirical study:}

\subsection{Statement of the problem}

According to statistics it is evident that Algerian economy is dependant of the energy sector's revenues. Last statistics show that hydrocarbons constituted $98 \%$ of exports revenues in 2013 (18) and oil rent about 22\% of GDP in 2013 (19). But, beside the good performance of the hydrocarbons sector due to high oil prices, there are other sectors and aspects of economic growth which are very important for long term prosperity and economic health. Though, despite the prosperity and positive economic growth statistics recorded lately, it is possible that Algerian dependence to natural resource revenues is harming the economic performance and may have destructive results on the long run. Algerian economy is performing poorly on several levels; such as trade openness and foreign direct investment which are two important elements for healthy economic growth on the long term. Thus, Algeria recorded poor performances 
on these two levels and still below the world average despite all the efforts and measures taken by Algerian government.

The following table shows the trade openness (20) index of Algerian economy in the period between 2004 and 2013:

Table 01: Trade openness index 2004-2013

\begin{tabular}{|c|c|}
\hline Year & Trade openness index \\
\hline 2004 & $66 \%$ \\
\hline 2005 & $71 \%$ \\
\hline 2006 & $71 \%$ \\
\hline 2007 & $72 \%$ \\
\hline 2008 & $77 \%$ \\
\hline 2009 & $71 \%$ \\
\hline 2010 & $70 \%$ \\
\hline 2011 & $68 \%$ \\
\hline 2012 & $67 \%$ \\
\hline 2013 & $63 \%$ \\
\hline
\end{tabular}

Source: The World Bank database

Despite the tiny progress, Algerian trade openness index is still below the world's average according to the World Bank statistics especially comparing to the MENA region countries.

The next table shows statistics about foreign direct investment in Algeria which is the second point of focus in this study:

Table 02: Foreign direct investment (billion dollars) 2004-2013

\begin{tabular}{|c|c|}
\hline Year & FDI (billion dollar) \\
\hline 2004 & 0.881 \\
\hline 2005 & 1.156 \\
\hline 2006 & 1.841 \\
\hline 2007 & 1.686 \\
\hline 2008 & 2.638 \\
\hline 2009 & 2.747 \\
\hline 2010 & 2.3 \\
\hline 2011 & 2.571 \\
\hline 2012 & 1.5 \\
\hline 2013 & 1.689 \\
\hline
\end{tabular}

Source: The World Bank database

As shown in table two, foreign direct investment in Algeria averaged between 0.881 billion to 2.747 billion dollars in the period between 2004 and 2013, which is low comparing to other countries in the MENA region and the world, for example in 2013 
Egypt recorded 4 billion dollars of FDI net inflows, Morocco 3.5 and the UAE 10.5 billion dollars, in the same year Indonesia recorded 23 billion dollars, Malaysia 11 and Brazil about 80 billion dollars (21).

The next table shows percentage of foreign direct investment in Algeria of GDP:

Table 03: Foreign direct investment (\% of GDP) 2004-2013

\begin{tabular}{|c|c|}
\hline Year & FDI (billion dollar) \\
\hline 2004 & $1 \%$ \\
\hline 2005 & $1.1 \%$ \\
\hline 2006 & $1.6 \%$ \\
\hline 2007 & $1.2 \%$ \\
\hline 2008 & $1.5 \%$ \\
\hline 2009 & $2 \%$ \\
\hline 2010 & $1.4 \%$ \\
\hline 2011 & $1.3 \%$ \\
\hline 2012 & $0.7 \%$ \\
\hline 2013 & $0.8 \%$ \\
\hline
\end{tabular}

Source: The World Bank database

As shown in table 03, the highest level of foreign direct investment in Algeria was about $2 \%$ of GDP recorded in 2009 and the lowest was $0.7 \%$ in 2012 , which is also far behind most of MENA countries and many other countries in the world.

Starting from the statistics shown above, the problem we are trying to underline is the poor performance of trade openness and foreign direct investment which can be harmful for Algerian economy in the future. In this study we are going to discuss the problem basing on the literature review, using the Dutch Disease theory and the resource curse approach, in order to provide empirical evidence that resource abundance is harming Algerian economy, otherwise said natural resource dependence is the main cause of the poor performance recorded in the other levels of Algerian economy.

\subsection{Hypotheses:}

Basing on literature review the following hypotheses are set:

H1: There is a statistically significant negative relationship between the energy sector dependence and trade openness in Algeria.

$\mathrm{H} 2$ : There is a statistically significant negative relationship between the energy sector dependence and foreign investment in Algeria.

\subsection{Methodology:}

In order to test the hypotheses, a classic linear regression model has been adopted in order to estimate parameters and correlation using time series data type. The study 
period extends from 2004 to 2013. The independent variable is economic dependence to natural resources measured by hydrocarbons percentage of total exports revenues, dependent variables are trade openness measured by percentage of imports and exports value of GDP, and foreign direct investment measured by net inflows (billion dollars) and percentage of GDP. Statistical analysis has been performed using the statistical package for social science software (SPSS) version 19 for windows.

Data is collected using the online databases of the World Bank, the CIA world factbook, IMF, and Algerian governmental institutions.

\section{Results}

\subsection{The effect of natural resource dependence on trade openness:}

Linear regression analysis results show that there is a negative relationship between natural resource dependence and trade openness. This relationship is economically and statistically significant. Calculated Spearman correlation $=-0.51$. Regression shows that an increase of $10 \%$ in hydrocarbons percentage of total exports revenues will result in a decrease of $3.62 \%$ in trade openness. Basing on these results the null hypothesis is rejected and the alternative hypothesis is accepted. Therefore, there is a significant negative impact of natural resource dependence on trade openness in Algeria. Furthermore, these results support the results of previous studies shown in literature review.

\subsection{The effect of natural resource dependence on FDI}

The second result of the study shows that there is also a negative relationship between natural resource dependence and foreign direct investment. This relationship is economically and statistically significant. Thus, the null hypothesis is rejected and the alternative hypothesis is accepted. Spearman correlation level is -0.45 between natural resource dependence and foreign direct investment net inflows and -0.64 between natural resource dependence and foreign direct investment percentage of GDP. Regression shows that an increase of $10 \%$ of hydrocarbons percentage of total exports revenues will result in a decrease of $7.07 \%$ in net inflows of foreign direct investment and will result in a decrease of about $3.94 \%$ in foreign direct investment percentage of GDP. These results also support the results of previous studies shown in literature review.

\section{Conclusions and recommendations}

\subsection{Conclusions}

Basing on the results pointed above, and considering that trade openness and foreign direct investment are both essential for economic growth, it is then evident that natural resource dependence is harming the Algerian economy and this might be the major obstacle facing the government's efforts to encourage foreign direct investment and increase trade openness. Oil rent is certainly contributing to the country's prosperity, but this welfare is shallow, because the rent doesn't reinforce the economy or the country's manufacturing sector. Actually, the rentier aspect of the Algerian economy is making it vulnerable and weak not just because of the sensitivity to oil price fluctuation but it also harms and obstructs the development of other sectors and 
most importantly manufacturing, this issue was discussed by many studies in literature in which usually is referred to as the Dutch Disease or the resource curse.

\subsection{Recommendations}

\subsubsection{For Algerian policy makers}

It would be more profitable and efficient for Algeria to invest the oil rent into productive fields and not just consumable projects. It is also important to identify the barriers facing foreign direct investment and trade openness then find radical solutions to stop the negative influence of natural resource abundance. Furthermore, it would be beneficial to use the results of some successful experience like Netherlands and Norway for escaping the resource curse and learn how to exploit the oil rent in a positive way to boost manufacturing and other sectors.

\subsubsection{Recommendations for future studies:}

Although the study shows that there is a negative relationship between natural resource dependence and both trade openness and foreign direct investment which means that resource abundance is harming the Algerian economy, the study doesn't explain the mechanism of Dutch Disease in Algeria and how does oil rent influence trade openness and foreign direct investment or whether the effect is direct through currency appreciation or indirect through corruption and rent seeking behavior. Therefore, it is important to follow with another study that aims to point the reason why natural resource dependence has a negative effect on the economy and determine the nature of this effect and furthermore determine to what extent do corruption and rent seeking behavior are involved in poor economical performance recorded in Algeria.

\section{References:}

1. Charlotte M. Levins, The Rentier State and the Survival of Arab Absolute Monarchies, Rutgers Journal of Law and Religion Vol 14, 2013, pp 388-423.

2. Rudiger Ahrend, How to Sustain Growth in a Resource Based Economy? The Main Concepts and their Application to the Russian Case, $5^{\text {th }}$ OECD Economics Survey, September 2004, p3.

3. Ibid, loc cit, p1.

4. Michael Herb, No Representation Without Taxation? Rents, Development and Democracy, Comparative Politics, Vol. 37, No. 3, City University of New York, April 2005, pp 297-316.

5. Thorvaldur Gylfason, Lessons from the Dutch Disease: Causes Treatment and Cures, STATOIL-ECON Conference: The Paradox of Plenty, 22 March 2001, $\mathrm{p} 1,2$.

6. Owen Barder, A Policymaker's Guide to Dutch Disease, Working Paper Number 91, Center for Global Development, July 2006, p4. 
7. W. Max Corden and J. Peter Neary, Booming Sector and De-Industrialisation in a Small Open Economy, The Economic Journal, Vol. 92, No. 368, December 1982, pp 825-848.

8. Mohamad Tahar Benkhoja, Monetary Policy and the Dutch Disease in a Small Open Oil Exporting Economy, Gate, France, 22 December 2011, p2.

9. W. Max Corden and J. Peter Neary, 1982, op cit, p826.

10. Idem.

11. Milan Brahmbhatt \& al, Dealing with Dutch Disease, The World Bank, Economic Premise, June 2010 No. 16, p2.

12. W. M. Corden, Booming Sector and Dutch Disease Economics: Survey and Consolidation, Oxford Economic Papers, Vol. 36, No. 3, November 1984, pp359380.

13. Milan Brahmbhatt \& al, loc cit, p2.

14. W. Max Corden and J. Peter Neary, 1982, op cit, p831.

15. E.g. Jefrey D. Sachs and Andrew M. Warner, The Curse of Natural Resources, Harvard University, European Economic Review 45, 2001, pp 827-338.

- Jefrey D. Sachs and Andrew M. Warner, Natural Resource Abundance and Economic Growth, Harvard University, November 1997.

- Michael Herb, No Representation, Without Taxation? Development and Democracy, University of New York, Comparative Politics Vol. 37, No. 3, April 2005, pp297-316.

16. E.g. Jonathan Isham \& al, The Varieties of Resource Experience: How Natural Resource Export Structures Affect the Political Economy of Economic Growth, Middlebury College Economics Discussions Paper No. 03-08, April 2003.

- Simon Dietz and Eric Neumayer, Corruption, The Resource Curse and Genuine Saving, Cambridge University Press, 2007.

- Matthias Busse and Steffen Gröning, Governance and Natural Resources, Hamburg Institute of International Economics, 2011.

17. Thorvaldur Gylfason, loc cit.

18. International Monetary Fund, Algeria Country Report No. 14/341, December 2014.

19. World Bank Database, http://data.worldbank.org/indicator/NY.GDP.PETR.RT.ZS, viewed: 10/08/2015.

20. Trade openness index is measured by the share of import and export of gross domestic product.

21. the World Bank Database.

22. the World Bank Database. 